\title{
ECLETICA
}

www.scielo.br/eq

Volume 31, número 4, 2006

\section{Immersion enthalpy variation of surface-modified mineral activated carbon in lead (II) aqueous solution adsorption: the relation between immersion enthalpy and adsorption capacity}

\author{
L. Giraldo ${ }^{1}$ and J.C. Moreno-Piraján ${ }^{2}$ \\ ${ }^{\prime}$ Department of Chemistry. School of Sciences. Universidad Nacional de Colombia. \\ ${ }^{2}$ Department of Chemistry. School of Sciences. Universidad de los Andes. Colombia.
}

\begin{abstract}
An activated carbon was obtained by chemical activation with phosphoric acid, CM, from a mineral carbon. Afterwards, the carbon was modified with 2 and 5 molL-1, CMox 2 and CMox 5 nitric acid solutions to increase the surface acid group contents. Immersion enthalpy at $\mathrm{pH} 4$ values and $\mathrm{Pb}^{2+}$ adsorption isotherms were determined by immersing activated carbons in aqueous solution. The surface area values of the adsorbents and total pore volume were approximately $560 \mathrm{~m}^{2} . \mathrm{g}^{-1}$ and 0.36 $\mathrm{cm}^{3} \mathrm{~g}^{-1}$, respectively. As regards chemical characteristics, activated carbons had higher acid sites content, $0.92-2.42 \mathrm{meq} \mathrm{g}^{-1}$, than basic sites, $0.63-0.12 \mathrm{meq}^{-1}$. $\mathrm{pH}$ values were between 7.4 and 4.5 at the point of zero charge, $\mathrm{pH}_{\mathrm{PZC}}$. The adsorbed quantity of $\mathrm{Pb}^{2+}$ and the immersion enthalpy in solution of different $\mathrm{pH}$ values for $\mathrm{CM}$ activated carbon showed that the values are the highest for $\mathrm{pH} 4,15.7$ $\mathrm{mgg}^{-1}$ and $27.6 \mathrm{Jg}^{-1}$ respectively. $\mathrm{Pb}^{2+}$ adsorption isotherms and immersion enthalpy were determined for modified activated carbons and the highest values were obtained for the activated carbon that showed the highest content of total acid sites on the surface.
\end{abstract}

Keywords: immersion enthalpy; $\mathrm{Pb}^{2+}$ adsorption; Langmuir isotherm; surface-modified.

\section{Introduction}

In a system where the adsorbate, that is a dissociated or protonated electrolyte, is under conditions in which the adsorption takes place; electrostatic interactions are produced, strongly influencing the metallic ions adsorption on activated carbons. Such interactions may be attractive or repulsive, depending on the adsorbent charge densities, ionic strength of the solution and kind of adsorbate [1].

The surface charge on the activated carbons is associated with the existence of heteroatoms and mainly, with the oxygen complexes content. Therefore, when an activated carbon is submerged in water, a charge produced by the dissociation of its functional groups occurs on its surface [2]. The adsorption of heavy metals in carbonaceous materials thus mainly occurs in the acid sites, such as lactonic and carboxylic groups $[3,4]$.

Among the heavy metal ions, $\mathrm{Pb}^{2+}$ is considered highly toxic and is kept in aqueous solution because of its ability to form complexes with the organic matter; therefore, the way in which this compound may be extracted from water using adsorbents and the factors that hinder such union are studied [5,6]. It is useful to study the energetic interactions occurring between the activated carbon and the surrounding aqueous solution by means of immersion enthalpy, because the metal adsorption from the solution shows the significant influence of the solvent that also occu- 
pies the available adsorption sites on solid surface. Consequently, the solution components reach an equilibrium where they interact in conjunction with the solid [7].

In this work, an activated carbon was prepared from mineral carbon, CM, and chemically activated with phosphoric acid, and $\mathrm{Pb}^{2+}$ adsorption isotherms, taken from aqueous solutions at different $\mathrm{pH}$ values were determined. Immersion enthalpies were also determined from activated carbon in order to establish relations with the adsorption parameters. Afterwards, two samples of activated carbon were obtained and their chemical surfaces were modified by oxidation with $\mathrm{HNO}_{3} 2$ and 5 molL-1, CMox 2 and CMox 5 solutions. Adsorption isotherms at a fixed $\mathrm{pH}$ and immersion enthalpies were then determined for these solutions.

\section{Experimental details}

\section{Previous treatment of the initial material}

The original mineral carbon was milled and sieved at an average particle size of 0.551 $\mathrm{mm}$ in order to obtain granular activated carbons. The material was then washed with distilled water, dried for 24 hours in an oven at $363 \mathrm{~K}$ and stored in dry plastic packages.

\section{Obtaining activated carbon through chemical activation}

For chemical activation, bituminous mineral carbon from the northern region of Colombia was taken and impregnated with a $\mathrm{H}_{3} \mathrm{PO}_{4}$ at $50 \%$ $\mathrm{v} / \mathrm{v}$ solution for 1 hour. The impregnated samples were then air dried at a temperature of $383 \mathrm{~K}$ for 4 hours. The activation process was carried out during 2 hours at $723 \mathrm{~K}$ and heating ramp of $10 \mathrm{Kmin}^{-}$ 1. A $\mathrm{N}_{2} 200 \mathrm{mLmin}^{-1}$ flow was maintained. Samples were then washed using distilled water until a conductivity of $5 \mu \mathrm{S} \mathrm{cm}-1$ was obtained for the water used.

When activated carbons are chemically prepared, one of the compounds usually used as activator is the phosphoric acid, since its dehydrating properties that enable it to react with the carbonaceous material and modify the carbonization process. Additionally, phosphoric acid intro- duces in the precursor and avoids its contraction during the heating, leaving spaces when it is removed in a later stage with washes. This way, generation of higher pore content takes place.

\section{Modification of the chemical surface with $\mathrm{HNO}_{3}$ solutions}

Quantities of approximately $5.000 \mathrm{~g}$ of activated carbon were taken and placed in contact with $50.0 \mathrm{~mL}$ of 2 and $5 \mathrm{molL}^{-1}$ nitric acid solutions at $323 \mathrm{~K}$. The samples were constantly stirred for a 1-h period [10], washed with distilled water to achieve a near neutral $\mathrm{pH}$ and dried in a stove at $343 \mathrm{~K}$.

\section{Textural analysis of the activated carbons obtained}

Textural characteristics were established through the determination of the $\mathrm{N}_{2}$ adsorption isotherms at $77 \mathrm{~K}$ in a conventional volumetric machine, Autosorb 3B, Quantachrome.

\section{Determining active sites}

Basic and acid sites of activated carbons were determined by the Boehm's method [11]. Acid sites were neutralized with a $\mathrm{NaOH} 0.1$ molL $^{-1}$ solution and basic sites with a $\mathrm{HCl} 0.1$ molL-1 solution. Carboxylic and lactonic sites were titrated with a $\mathrm{Na}_{2} \mathrm{CO}_{3} 0.1$ molL $^{-1}$ solution, carboxylic sites with a $\mathrm{Na}_{2} \mathrm{CO}_{3} .0 .1$ molL $^{-1}$ solution and phenolic sites were estimated by calculating the difference [12]. For the determinations, 50 $\mathrm{mL}$ of the solution was placed into contact with $1.000 \mathrm{~g}$ of activated carbon in a glass flask for 5 days at a constant temperature of $298 \mathrm{~K} .10 \mathrm{~mL}$ was titrated using a 0.1 molL $^{-1}$ of the corresponding solution. Measurements for titting were performed using a CG 840B Schott $\mathrm{pH}$ meter.

Determining the point of zero charge, PZC. Mass Titting method

Activated carbons ranging 10 to $600 \mathrm{mg}$ were taken. Each was placed in a $50.0 \mathrm{~mL}$ glass flask and $10.0 \mathrm{~mL}$ of sodium chloride, $\mathrm{NaCl},(0.1$ molL ${ }^{-1}$ ) was added,. Flasks were sealed and stirred and room temperature was maintained at $298 \mathrm{~K}$ for 48 hours to achieve equilibrium in carbon charges. After 48 hours, $\mathrm{pH}$ of each solution was measured with a CG 840B Schott $\mathrm{pH}$ meter [13]. 
$\mathrm{Pb}^{2+}$ adsorption equilibrium data

$\mathrm{Pb}^{2+}$ solutions were prepared from $\mathrm{Pb}(\mathrm{NO})_{3}$ within a concentration range of 20 to $100 \mathrm{mgL}^{-1}$ and the $\mathrm{pH}$ value was adjusted to 2, 4, 6 and 8, depending on the case, with solutions of $\mathrm{HCl} 0.01 \mathrm{molL}^{-1}$ and $\mathrm{NaOH} 0.01 \mathrm{molL}^{-1}$. A quantity of 0.100 to $0.250 \mathrm{~g}$ of activated carbon obtained from the mineral carbon, CM, was placed in a glass flask containing $250 \mathrm{~mL}$ of the corresponding $\mathrm{Pb}^{2+}$ solution. The solution was stirred and kept at $298 \mathrm{~K}$ to achieve equilibrium in carbon charges.

$\mathrm{Pb}^{2+}$ concentration in aqueous solution was determined by atomic absorption using a Perkin-Elmer AAnalyst 300 and evaluation was performed using calibration curves [7]. Calibration curves were prepared for all of the $\mathrm{pH}$ values tested in this work.

Once the maximum adsorption $\mathrm{pH}$ was chosen for the initial activated carbon, CM, isotherms were determined at $298 \mathrm{~K}$ and this $\mathrm{pH}$ value for the modified activated carbon samples CMox2 and CMox5.

\section{Determining immersion heats}

In order to determine the immersion enthalpy a heat conduction microcalorimeter with a stainless calorimetric cell was used [14]. The cell was filled with $30 \mathrm{~mL}$ of the chosen solution, $\mathrm{Pb}^{2+} 100 \mathrm{mgL}^{-1}$, (kept in a thermostat) at $298 \mathrm{~K}$ at a fixed $\mathrm{pH}$. A sample of activated carbon weighing approximately $0.250 \mathrm{~g}$ was placed in a calorimetric cell inside a glass ampoule and the microcalorimeter was assembled. When the equipment reached a temperature of $298 \mathrm{~K}$, the potential output record began. This lasted for a period of approximately 15 minutes with potential reading taken every 20 seconds. The glass ampoule was then broken; the thermal effect generated was recorded and the readings corresponding to the potential continued for approximately 15 more minutes until, finally, it was electrically calibrated.

\section{Results and Discussion}

For the mineral carbon used as a precursor, a fixed carbon content of $58 \%$ was found.
This was a good choice for an initial material in order to obtain an activated carbon because after the thermal treatment of the final activated carbons, the fixed carbon contents will increase [15]. The volatile matter was approximately $29 \%$ and the ash content, 5.5\%. These values agree previous studies in which a mineral carbon was used as a precursor. Such contents have a subsequent influence on the development of the porosity for the obtained activated carbon. [16].

Table 1 shows the results obtained when the textural analysis was performed for the prepared activated carbons. The surface area was determined by the BET method, $\mathrm{S}_{\mathrm{BET}}$ in $\mathrm{m}^{2} \mathrm{~g}^{-1}$; total pore volume, $\mathrm{V}_{\mathrm{T}}$, in $\mathrm{cm}^{3} \mathrm{~g}^{-1}$ and the micropore volume, $\mathrm{V} \mu \mathrm{p}$, in $\mathrm{cm}^{3} \mathrm{~g}^{-1}$.

Table 1. Textural analysis of the obtained activated carbons

\begin{tabular}{|c|c|c|c|}
\hline $\begin{array}{c}\text { Activated } \\
\text { Carbon }\end{array}$ & $\begin{array}{c}\mathbf{S}_{\text {BET }} \\
\left(\mathrm{m}^{2} \cdot \mathrm{g}^{-1}\right)\end{array}$ & $\begin{array}{c}\mathbf{V}_{\mathbf{T}} \mathbf{N}_{\mathbf{2}} \mathbf{7 7 K} \\
\left(\mathrm{cm}^{3} \mathrm{~g}^{-1}\right)\end{array}$ & $\begin{array}{c}\mathbf{V}_{\mu \mathbf{p}} \mathbf{N}_{\mathbf{2}} \mathbf{7 7 K} \\
\left(\mathrm{cm}^{3} \mathrm{~g}^{-1}\right)\end{array}$ \\
\hline CM & 586 & 0.37 & 0,28 \\
\hline CMox2 & 567 & 0.36 & 0.27 \\
\hline CMox5 & 552 & 0.36 & 0.25 \\
\hline
\end{tabular}

From results shown in Table 1 it may be seen that the chemical activation process is efficient because it activates for a 2 -h period at a moderate temperature of $723 \mathrm{~K}$. The burning rate was about $40 \%$ higher than the obtained under such conditions in physical activation; likewise, both the surface area, $586 \mathrm{~m}^{2} \mathrm{~g}^{-1}$, and the pore volume present higher values than the ones reported in scientific literature for the activation of carbonaceous materials through the physical activation method [17]. In addition, for activated carbons that use mineral carbons as precursors, higher performance is obtained since they present greater carbon contents. However, in some cases, there are higher ash contents than in vegetable materials that may affect the activation process [16].

For the activated carbon samples treated with $\mathrm{HNO}_{3}$, slightly lower values were reported both for the surface area and micropore volume. These results agree with other studies reported in 
the literature [10] and may be associated with the elimination of the porosity in the original activated carbon.

Table 2 shows the results of the contents of the surface functional groups on the activated carbons with the number of total acid sites, in meqg1. To chart results, the number of phenolic groups, carboxylic groups and lactonic groups were determined. The content of total basic sites and the $\mathrm{pH}$ at the point of zero charge are also shown. As it can be seen, the acid site content is higher than the basic site content for the three samples, with values ranging between 0.92 and 2.42 meqg $^{-1}$. Such results show the modification in the contents of the surface acid group when the original activated carbon, CM, is treated with nitric oxide. Likewise, it was observed that the carboxylic acid-type groups are predominant; this characteristic boosts the adsorption of charged solutes from the aqueous solution. As regards the values for the $\mathrm{pH}_{\mathrm{PZC}}$, for the original activated carbon, CM, a value of 7.4 is reported and for the other two samples, this value decreases with the increase of the surface acid sites content. Therefore, the activated carbon charge will be positive for a solution $\mathrm{pH}$ lower than the $\mathrm{pH}_{\mathrm{PZC}} 1$ [1].

After determining the characteristics of the activated carbons, the adsorption isotherms were performed at different $\mathrm{pH}$ values, 2 to 8 , for the unaltered activated carbon, CM. This was done to determine the maximum adsorption $\mathrm{pH}$ value and to subsequently obtain isotherms for the unmodified activated carbons CMox 2 and CMox 5 for the $\mathrm{pH}$ value.
The adsorption isotherms of activated carbon $\mathrm{CM}$ at different $\mathrm{pH}$ values of the solution are graphed in Figure 1; the figure displays the $\mathrm{Pb}^{2+}$ quantity adsorbed per gram of activated carbon in function of equilibrium concentration.

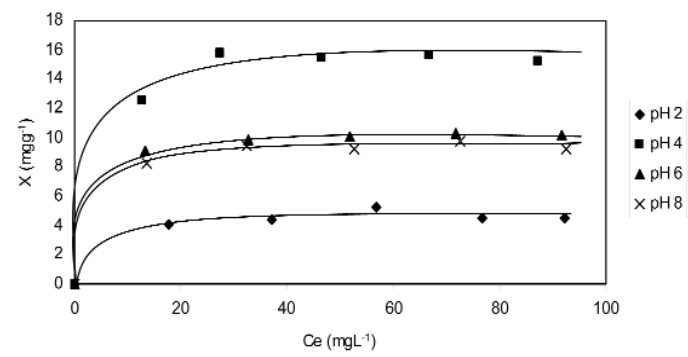

Figure 1. $\mathrm{Pb}^{2+}$ adsorption isotherms in chemically activated carbon at different $\mathrm{pH}$ values. Temperature $298 \mathrm{~K}$.

It can be seen that the $\mathrm{Pb}^{2+}$ ion adsorption in the $\mathrm{CM}$ activated carbon is high for $\mathrm{pH} 4$, intermediate for $\mathrm{pH} 6$ and 8, and low at $\mathrm{pH} 2$. These liquid phase isotherms are of the Langmuir type, which are common when the adsorption of a solute in diluted solutions is studied [18].

Figure 2 shows the typical thermograms obtained when the activated carbons $\mathrm{CM}$ and CMox 5 are immersed in $\mathrm{Pb}^{2+}$ ion $100 \mathrm{mgL}^{-1}$ solution. In this figure, heat is proportional to the area under the slope and a higher effect can be observed when the treated sample is immersed in a $5 \mathrm{M} \mathrm{HNO}_{3}$ solution.

Table 2. Chemical analysis of activated carbons. Determination of basic sites, acid sites and point of zero charge, $\mathrm{pH}$ Pzc.

\begin{tabular}{|c|c|c|c|c|c|c|}
\hline $\begin{array}{c}\text { Activated } \\
\text { Carbon }\end{array}$ & $\begin{array}{c}\text { TOTAL } \\
\text { Acid } \\
\text { Sites }^{\mathrm{a}} \\
\text { meq g }^{-1}\end{array}$ & $\begin{array}{l}\text { Phenolic } \\
\text { Groups } \\
\text { meq g }^{-1}\end{array}$ & $\begin{array}{c}\text { Carboxylic } \\
\text { Groups } \\
\text { meq g }^{-1}\end{array}$ & $\begin{array}{l}\text { Lactonic } \\
\text { Groups } \\
\text { Meq g }^{-1}\end{array}$ & $\begin{array}{c}\text { TOTAL } \\
\text { Basic } \\
\text { Sites }^{\mathrm{a}} \\
\text { meq g }^{-1}\end{array}$ & $\mathbf{p H}_{\mathrm{PZC}}$ \\
\hline $\mathrm{CM}$ & 0.92 & 0.21 & 0.41 & 0.30 & 0.63 & 7.4 \\
\hline Cmox 2 & 1.60 & 0.55 & 0.72 & 0.33 & 0.38 & 5.2 \\
\hline Cmox 5 & 2.42 & 0.69 & 1.15 & 0.58 & 0.12 & 4.5 \\
\hline
\end{tabular}




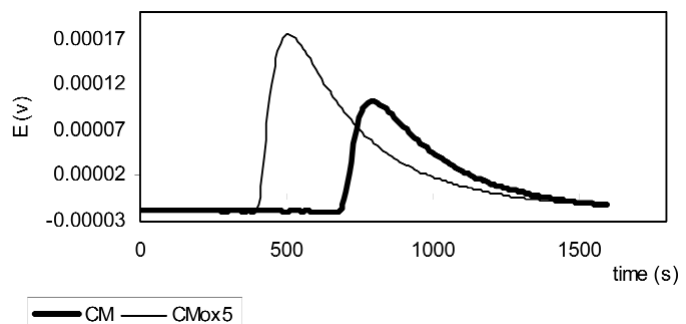

Figure 2. Immersion thermograms of $\mathrm{CM}$ and Cmox 5 in the $100 \mathrm{mgL}^{-1} \mathrm{~Pb}^{2+}$ solution.

Table 3 displays the results obtained for the ion metallic adsorption on the initial activated carbon, $\mathrm{CM}$, at different $\mathrm{pH}$ values for the de $\mathrm{Pb}^{2+}$ quantity adsorbed in the monolayer, $\mathrm{Xm}$, in $\mathrm{mgg}^{-1}$, the adsorption constant, $\mathrm{k}$ in $\mathrm{Lmg}^{-1}$ and the activated carbon immersion enthalpy in a solution of $100 \mathrm{mgL}^{-1}, \Delta \mathrm{Him}$ in $\mathrm{Jg}^{-1}$.

The maximum values are observed for the adsorption and immersion enthalpy at $\mathrm{pH} 4$, which indicates that under such experimental conditions, the interaction between the activated carbon $\mathrm{CM}$ and the aqueous solution varies when $\mathrm{pH}$ values change. The lowest interaction was observed at $\mathrm{pH}$ 2 , a behavior similar to that of carbonaceous materials reported in scientific literature [18]. According to the $\mathrm{Pb}^{2+}$ speciation diagram, these are the dominant species at a $\mathrm{pH}$ above $4: \mathrm{Pb}(\mathrm{OH})^{+}$, $\mathrm{Pb}(\mathrm{OH})_{2}, \mathrm{~Pb}(\mathrm{OH})_{4}{ }^{2-}$ and $\mathrm{Pb}(\mathrm{OH})_{3}{ }^{-}$. In acid media, the surface of solid is protonated and adsorption occurs in hydroxylated forms of lead. With the $\mathrm{pH}$ increase, the protonation of the carbon surface is gradually reduced and a decrease in the adsorption is observed. The $\mathrm{pb}^{2+}$ adsorption depends on the surface characteristics of the activated carbon, such as surface area and pore volume. In the present study, it may be seen that both properties are similar and there is a considerable variation in the acid groups content influencing the quantity adsorbed on the monolayer, Xm. Thereby, the highest value for CMox 5, $24.6 \mathrm{mgg}^{-1}$, has the highest content of total acid groups.

From the shown results, it can be seen that at $\mathrm{pH} 4$, the highest $\mathrm{Pb}^{2+}$ adsorption is observed and this value is taken as a basis to determine the isotherms at $298 \mathrm{~K}$ for the chemically modified carbons, in which the total increase of acid sites increased. Therefore, the interaction between the solid and the solution will be influenced. Figure 3 shows the isotherms obtained for the three carbons activated in this study. The $\mathrm{Pb}^{2+}$ adsorption increased for the activated carbon CMox5, which has the highest content of the total acid sites.

Table 4 summarizes the results for the adsorption and $\mathrm{Pb}^{2+}$ immersion enthalpy on the activated carbons $\mathrm{CM}, \mathrm{CMox} 2$ and $\mathrm{CMox} 5$ at $\mathrm{pH} 4$. Again, the Langmuir model is applied to experi-

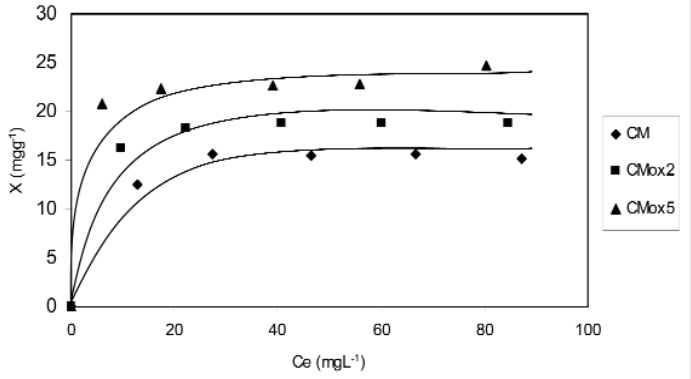

Figure 3. $\mathrm{Pb}^{2+}$ adsorption isotherms from activated carbons with different content of total acid sites on their surface. Temperature. $298 \mathrm{~K}$.

Table 3. Langmuir model constants for $\mathrm{Pb}_{2+}$ adsorption in unmodified activated carbon CM and immersion enthalpy

\begin{tabular}{|c|c|c|c|}
\hline $\mathbf{p H}$ & $\begin{array}{c}\mathbf{X m} \\
\left(\mathrm{mgg}^{-1}\right)\end{array}$ & $\begin{array}{c}\mathbf{K} \\
\left(\mathrm{Lmg}^{-1}\right)\end{array}$ & $\begin{array}{c}-\Delta \mathbf{H i m}^{\mathbf{a}} \\
\left(\mathrm{Jg}^{-1}\right)\end{array}$ \\
\hline 2 & 4.61 & 2.66 & $10.4 \pm 0.52$ \\
\hline 4 & 15.7 & 0.69 & $27.6 \pm 1.15$ \\
\hline 6 & 10.5 & 0.54 & $18.2 \pm 0.82$ \\
\hline 8 & 9.53 & 0.83 & $17.5 \pm 0.78$ \\
\hline${ }^{a}$ Average of three determinations
\end{tabular}


Table 4. Results of the interaction between activated carbon and $\mathrm{Pb}_{2}+$ solution in samples with different contents of total acid sites

\begin{tabular}{|c|c|c|c|}
\hline Activated carbon & $\begin{array}{c}\mathbf{X m} \\
\left(\mathrm{mgg}^{-1}\right)\end{array}$ & $\begin{array}{c}\mathbf{k} \\
\left(\mathrm{Lmg}^{-1}\right)\end{array}$ & $\begin{array}{c}-\Delta \mathbf{H i m}^{\mathbf{2}} \\
\left(\mathrm{Jg}^{-1}\right)\end{array}$ \\
\hline $\mathrm{CM}$ & 15.7 & 0.69 & $27.6 \pm 1.15$ \\
\hline CMox2 & 18.9 & 0.78 & $31.4 \pm 1.29$ \\
\hline CMox5 & 24.6 & 0.44 & $36.1 \pm 1.73$ \\
\hline
\end{tabular}

${ }^{a}$ Average of three determinations

mental data. The table displays the quantity adsorbed in the monolayer, $\mathrm{Xm}$, in $\mathrm{mgg}^{-1}$; the adsorption constant, $\mathrm{k}$, in $\mathrm{Lmg}^{-1}$ and the activated carbon immersion enthalpy in a solution of 100 $\mathrm{mgL}^{-1}, \Delta$ Him, in $\mathrm{Jg}^{-1}$.

It is observed that the interaction between the solid and the solution rises with the increase of the acid site content, which is expressed by the adsorption of a higher quantity, $24.6 \mathrm{mgg}^{-1}$, and an increased immersion enthalpy of $36.1 \mathrm{Jg}^{-1}$ for the activated carbon CMox5. Even if higher values are observed for the lactonic, carboxylic and phenolic groups, as well as for the modified activated carbons, carboxylic groups present the highest increase rate and they are supposed to boost the interaction.

Figure 4 shows the interactions between the total acid site content and the $\mathrm{Pb}^{2+}$ quantity adsorbed in the monolayer and immersion enthalpy for the activated carbons. In both cases, the tendencies are linear, with correlation coeffi-

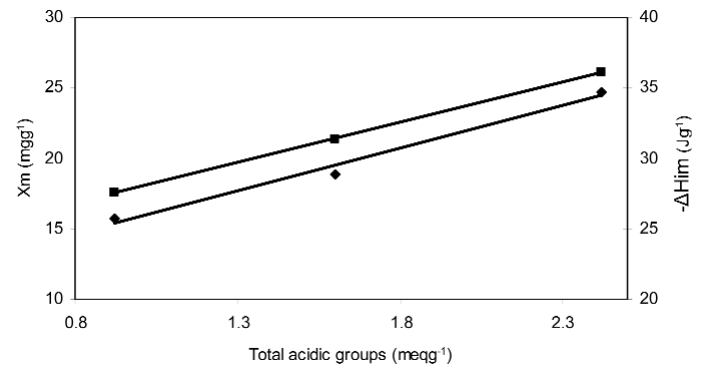

Figure 4. Relation between the total acid site content, the $\mathrm{Pb}^{2+}$ quantity adsorbed on the monolayer and the immersion enthalpy. cients of 0.98 and 0.99 respectively. This indicates that the increase in the surface acid site content boosts the interaction with the metallic ion.

The k constant obtained in the Langmuir model is related to the interaction produced in the adsorption process [15], as the $\mathrm{k}$ constant represents the immersion enthalpy of the solid in the solution. The relation between these values is shown in Figure 5, in which a non-linear tendency is observed for the three experimental points. This validates the existing relation between both characteristics established in $\mathrm{Pb}^{2+}$ adsorption from the aqueous solution on activated carbons.

In the aqueous solution, the solid-liquid interaction is influenced by the charge, both from the solid and the solutes that are dissociated. In this case, the solid surface charge is represented in the $\mathrm{pH}$ of the point of zero charge, $\mathrm{pH}_{\mathrm{PZC}}$. Thus, there is a relationship among such value, the $\mathrm{Pb}^{2+}$ adsorbed quantity on the monolayer and the immersion enthalpy, as shown on Figure 6.

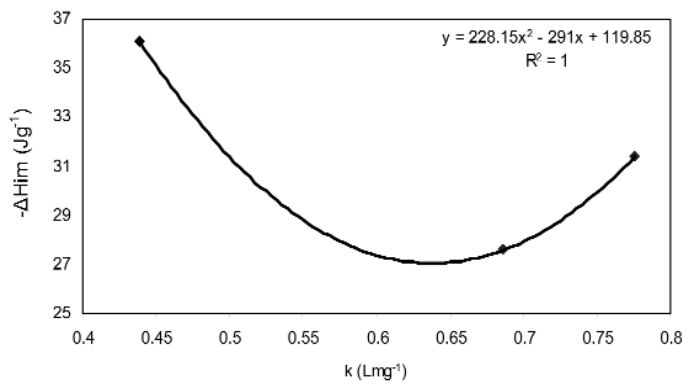

Figure 5. Relation between the k constant of the Langmuir model and immersion enthalpy. 


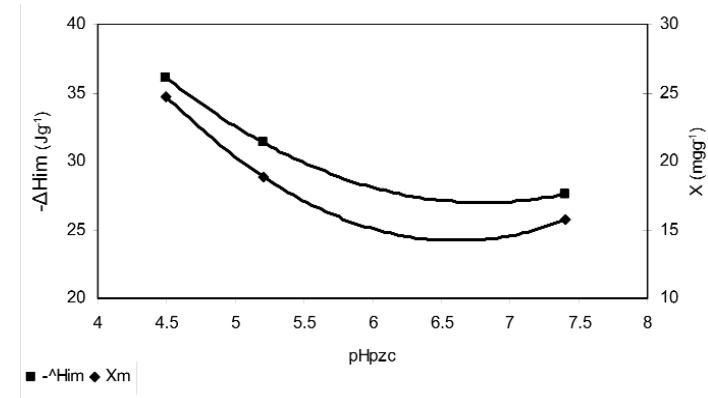

Figure 6. Relation among the $\mathrm{pH}$ at the point of zero charge, the quantity of adsorbed $\mathrm{Pb}^{2+}$ on the monolayer and immersion enthalpy.

The experiment showed similar relationships, indicating the way in which the adsorbed quantity and immersion enthalpy are influenced by the surface solid properties, in addition to their surface area and pore volume. To notice this influence, it is important to keep in mind that metallic ion adsorption on the activated carbon depends on the surface characteristics, such as surface area, pore structure and surface acidity and solutions properties. For the systems studied, the activated carbons show surface areas of about $560 \mathrm{~m}^{2} \mathrm{~g}^{-1}$, which were similar for the three samples, and an acid group content of 0.92 and 2.42 meqg ${ }^{-1} \cdot \mathrm{Pb}^{2+}$ adsorption capacity shows a higher influence of the surface group content.

\section{Conclusions}

An activated carbon was obtained from the mineral carbon prepared by means of chemical activation and the surface properties of this carbon are adequate for the liquid-phase adsorption. The activated carbon was superficially modified using nitric acid and in all cases, the total acid sites content was higher than the content of the total basic sites.

For the original sample, adsorption isotherms were determined at $298 \mathrm{~K}$ at different $\mathrm{pH}$ values, and the highest adsorption and immersion enthalpy appeared at $\mathrm{pH} 4$. The isotherms and quantities of adsorbed $\mathrm{Pb}^{2+}$ represent the major evidence of the influence of the solution conditions in the adsorption process.

The samples of modified activated carbons presented higher values for the adsorbed quantity on the monolayer and for the immersion enthalpy with respect to the original activated carbon. These are directly proportional to the number of total acid sites.

\section{Acknowledgements}

The authors wish to thank the Master Agreement established between the "Universidad de los Andes" and the "Universidad Nacional de Colombia" and the Memorandum of Understanding entered into by the Departments of Chemistry of both universities.

\section{Received 12 September 2006}

Accepted 08 November 2006.

\section{References}

[1] C. Moreno-Castilla, Carbon 42 (2004) 83-94.

[2] L. R. Radovic, C. Moreno-Castilla, J. Rivera-Utrilla, In: Chemistry and Physics of Carbon, A Series of Advances, Ed Marcel Dekker, New York, 2000, 293-297.

[3] Y. Kikuchi, Q. Quian, M. Machida, H.Tatsumoto, Carbon 44 (2006) 195-202.

[4] M. Machida, Y. Kikuchi, M. Aikawa, H. Tatsumoto, A: Physicochem Eng Aspects, Colloids Surf 240 (2004) 79-86. [5] A. Macias-García, C. Valenzuela-Calahorro, A. EspinosaMansilla, A. Bernalte-Garcia, B. Gómez-Serrano, Carbon 42 (2004) 1755-1764.

[6] M. Fan, T. Boonfueng,Y. Xu, L. Axe, T. A. Tyson, J. Colloid of Interface Science 281 (2005) 39-48.

[7] L.Giraldo, J. C. Moreno, Revista Colombiana de Química 33(2) (2004) 87-97.

[8] F. Rodríguez-Reinoso, Encyclopedia of Materials, Science and Technology, New York, 2001, 22-30.

[9] M.C. Baquero, L. Giraldo, J. C. Moreno, F. SuárezGarcía, A. Martínez-Alonso, J. Tascón JMD, Appl. Pyrolysis 70 (2003) 779-784.

[10] A. Abdel-Naser, Hendawy-El, Carbon 41 (2003) 713-722.

[11] H.P. Boehm, Advances in Catalysis, D.D. Eley, H. Pines, P.B.Weisz, Eds. Academic Press. New York., 1966,192-200.

[12] F.S. Mohamed, W.A. Khater, M.R. Mostafa, Chem. Eng. Journal 116 (2006) 47-52.

[13] M. Kosmulski, J. Colloid. Inter. Scien. 275 (2004) 214-224.

[14] L.Giraldo, J.C. Moreno, J.I.Huertas, Instrumentation Science \& Technology. 30(2) (2002) 177-186.

[15] F. Rodríguez-Reinoso, Activated carbon: structure, characterization, preparation and applications. En: Introduction to carbon technologies. Universidad de Alicante (Publicaciones). Alicante, España.,1997, 60-70.

[16] A. Linares-Solano, J. Martín-Gullon, C. Salinas-Martínez de Lecea, B. Serreno-Talavera, Fuel 79 (2000) 635-643.

[17] M. A.Lillo-Ródano, D. Lozano-Castelló, D. CazorlaAmorós, A. Linares-Solano, Carbon 39 (2001) 751-759.

[18] K. Laidler, J.Meiser, Fisicoquímica, Ed. Cecsa, México, ed 2 th , 2002, 234-260. 